\title{
Retinal Blood Flow Evaluation
}

\author{
Constantin J. Pournaras ${ }^{a} \quad$ Charles E. Riva ${ }^{b}$ \\ aDepartment of Ophthalmology, Vitreo-Retinal Unit, Geneva University Hospitals, Geneva, and \\ b Prof. em., Medical School, University of Lausanne, Lausanne, Switzerland
}

\section{Key Words}

Retinal blood flow · Retinal Vessel Analyzer - Laser Doppler velocimetry $\cdot$ Laser Doppler flowmetry $\cdot$ Laser speckle flowgraphy $\cdot$ Color Doppler imaging $\cdot$ Retinal ischemic microangiopathy

\section{Abstract}

Much of our basic knowledge of retinal blood flow regulation is based on data obtained from animal experiments through the use of invasive techniques. However, during the last decades, major developments in the field of optics and lasers have led to a variety of noninvasive techniques, which have been applied to the human eye for the investigation of retinal hemodynamics, and more specifically the regulation of retinal blood flow in response to a number of physiological and pharmacological stimuli. The Retinal Vessel Analyzer has markedly simplified the measurement of the diameter of retinal vessels, as well as the change in this diameter evoked by various physiological stimuli (dynamic measurements). Bidirectional laser Doppler velocimetry allows the measurement of absolute red blood cell centerline velocity, which, when combined with the diameter allows the calculation of retinal blood flow in the main retinal vessels. Laser Doppler flowmetry and laser speckle flowgraphy are techniques that measure the velocities of blood in discrete areas of the retinal tissue microcirculation. Adding a scanning capability, a spatial map of velocities across the retinal tissue is obtained. The blue-field simulation technique allows the quantification of the velocity, number and velocity pulsatility of leukocytes moving in the retinal capillaries of the macular region. With color Doppler imaging, the peak systolic and end-diastolic values of blood velocity in the ophthalmic and central retinal artery are measured, from which a resistivity index is obtained. These techniques may help better understand the role of altered retinal blood flow and its regulation in the pathogenesis of retinal diseases of vascular origin.

Copyright $\odot 2012$ S. Karger AG, Basel

\section{Introduction}

The retinal circulation supplying the fundus of the eye can be observed using optical instruments that allow the recording of either the vessel diameter or the passage of dyes through the human retinal vascular system, from which the first quantitative measurements of retinal hemodynamics were derived [1].

Technological developments in the field of optics and lasers have since led to a variety of noninvasive tech-

\section{KARGER \\ Fax +4161306 1234 \\ E-Mail karger@karger.ch}

www.karger.com
(C) 2012 S. Karger AG, Basel

0030-3755/13/2292-0061\$38.00/0

Accessible online at:

www.karger.com/oph
Prof. Constantin J. Pournaras

La Colline, Ophtalmologie

Avenue de La Roseraie, 76A

$\mathrm{CH}-1205$ Genève (Switzerland)

E-Mail constantin.pournaras@lacolline.ch 
niques, which have permitted the investigation of various parameters pertaining to human ocular hemodynamics and the response of these parameters to a number of physiological and pharmacological stimuli.

These techniques have provided information on human retinal circulatory physiology and have led to new, important information on the role of retinal blood flow in the pathogenesis of retinal diseases of vascular origin.

\section{General Hemodynamic Considerations}

Blood flow $(B F)$ through a blood vessel depends upon the perfusion pressure $(P P)$, i.e. the pressure that drives blood through the vessel, and the flow resistance $(R)$ generated by the vessel. For an incompressible uniform viscous liquid (dynamic viscosity, $\eta$ ) flowing through a cylindrical tube (length $L$ ) with radius $(r), B F$ is given by the Hagen-Poiseuille law: $B F=P P / R$, where $R=\eta L / 2 \pi r^{4}$. Many factors make it difficult to directly apply this law to a microvascular bed. These include the $\eta$ dependence on local hematocrit, the changes in the velocity profile of the red blood cells (RBCs) and shear rate at branchings and junctions and others.

Another approach at characterizing BF through a system of blood vessels is based on Murray's law [2], which says that through each vessel of a circulatory system with optimal design (blood flowing with minimal loss of energy) $B F=k\left(r^{3} / \sqrt{\eta}\right)$. The constant $k$ depends upon $L$ and $r$ [3].

The mean ocular $P P$ driving blood through the eye is the mean blood pressure in the ophthalmic artery minus the pressure in the veins leaving the eye. The venous pressure is close to the intraocular pressure (IOP) [4]. With the subject in sitting or standing position, mean ocular $P P$ is about $2 / 3$ of the mean brachial artery blood pressure $(A B P)$, i.e.

$$
P P=2 / 3\left[A B P_{\text {diast }}+1 / 3\left(A B P_{\text {syst }}-A B P_{\text {diast }}\right)\right]-I O P .
$$

The factor $2 / 3$ stands for the drop in pressure between the heart and the ophthalmic artery. $A B P_{\text {diast }}$ and $A B P_{\text {syst }}$ are the brachial $A B P$ during diastole and systole, respectively. It is understood that this expression for $P P$ is based on a group average and therefore provides only an approximate value for a single individual. The value of $\eta$ has been experimentally related to hematocrit at defined shear rates. It diminishes with increasing shear rate to become almost constant with further decreases of this rate [5]. An increase in viscosity (e.g. in cases of hyperglobulinemia, high hematocrit, leukemia, sickle cell anemia) substantially alters retinal $B F$, which may induce stasis in the veins and ultimately their occlusion [6].
The main resistance to $B F$ is located in the arterioles with half of the resistance in vessels with a radius of $10-25$ $\mu \mathrm{m}$. As $R$ is proportional to $1 / r^{4}$, even a small change in $r$ will have a considerable effect on $R$; $r$ and consequently the diameter $(D)$ of a vessel is modulated by the interaction of multiple systemic and local control mechanisms affecting the tone of the smooth muscle cells and perhaps the pericytes.

Alterations in retinal vessel $D$ have been linked to several vascular related pathologies, including systemic hypertension and diabetes, in large population-based studies. Abnormal retinal vascular regulation may also be identified through metabolic provocation, such as flicker stimulation of the retina. Thus, the ability to obtain exact measurements of $D$ is of crucial importance to our understanding of retinal $B F$ and its regulation during the evolution of retinal ischemic microangiopathies.

\section{Noninvasive Techniques Used in Physiological and Clinical Research}

In the last decades the development of noninvasive techniques has led to new and important information on retinal hemodynamics and $B F$ regulation in the healthy and diseased human eye. These techniques include the measurements of the following retinal hemodynamic parameters: $D$, using photography or video recording and the newly developed Retinal Vessel Analyzer (RVA); mean circulation time $(M C T)$ and arteriovenous passage time $(A V P)$ of fluorescein through retinal segments by the dye dilution technique; velocity and number of leukocytes in the macular area by the blue-field simulation technique; velocity of fluorescent leukocytes and hyperfluorescent segments in retinal capillaries by video angiography; velocity and RBC flow in the main retinal vessels using bidirectional laser Doppler velocimetry (BLDV) combined with the measurement of $D$; blood flow in the tissue of the optic disk and peripapillary retina by laser Doppler flowmetry (LDF) and central retinal arterial blood velocity by color Doppler imaging.

\section{Measurement of D of Retinal Vessels}

$D$ has been measured in the past from magnified fundus photographs using a caliper or by scanning across the vessels [7, 8]. In recent years, the RVA has markedly simplified this measurement $[9,10]$, allowing also the quasi-continuous recording of $D$ changes evoked by various physiological maneuvers (dynamic measurements) (fig. 1). 
In principle, the RVA assesses $D$ by analyzing the brightness profile of the vessel. This assessment is based on the fact that the green light used for fundus illumination is mostly absorbed by the RBCs within the retinal vessels, whereas the environment mostly reflects this light. Thus, the RVA measures mainly the width of the RBC column within the selected vessels.

The interpretation of the vessel brightness map is hampered by the possible occurrence of several disturbances, such as shadowing structures or reflections on the vessel surface, which complicate the analysis. To overcome this problem, the RVA uses an adaptive algorithm based on variation in brightness, which compensates for reflections and other disturbances that occur during measurement.

With the RVA, a vessel is scanned 25 times/s within a rectangular window having a length of about $1.5 \mathrm{~mm}$ and a width slightly larger than the diameter of the vessel. After determination of the angle between the vessel and the direction of the window, $D$ is calculated automatically. The RVA is particularly well suited for the evaluation of the temporal dynamic of $D$ in response to various physiological stimuli, pharmacological and therapeutic agents (fig. 1). The technique requires dilatation of the pupil. Using vessels with a $D>90 \mu \mathrm{m}$, it is possible to obtain a precision in $D$ of the order of $1 \mu \mathrm{m}$. Temporal resolution of $D$ recordings is about $40 \mathrm{~ms}$.

Studies have reported that long- and short-term reproducibility of $D$ measurements is slightly higher for retinal veins than for retinal arteries, probably reflecting a better optical resolution of veins (in comparable fundus locations, veins are larger than arteries) or differences in the absorption properties of arteries compared with veins [10].

The short-time coefficient of variation $(\mathrm{CV})$ of $D$ was assessed in a group of 9 healthy volunteers. The CVs of $D$ for measurements taken $12 \mathrm{~min}$ apart have been reported to be 1.3 and $2.6 \%$ for retinal veins and retinal arteries, respectively. The CVs for the day-to-day variability of $D$ were $4.4 \%$ for retinal veins and $5.2 \%$ for retinal arteries in the same group of volunteers [11].

$D$ of retinal veins was assessed continuously for $5 \mathrm{~min}$ in 12 healthy volunteers and the measurements were repeated at the same vessel location after $2 \mathrm{~h}$. This resulted in a short-term CV of $D$ of $1.5 \%$ for retinal veins. The same study assessed long-term reproducibility comparing measurements at baseline and after 1 month. The reported CV of $D$ was $2.8 \%$ for retinal veins [12]. CV of $D$, determined for short-term (less than $2 \mathrm{~h}$ ) and long-term ( 2 weeks), was 1.5 and $2.8 \%$, respectively [10].

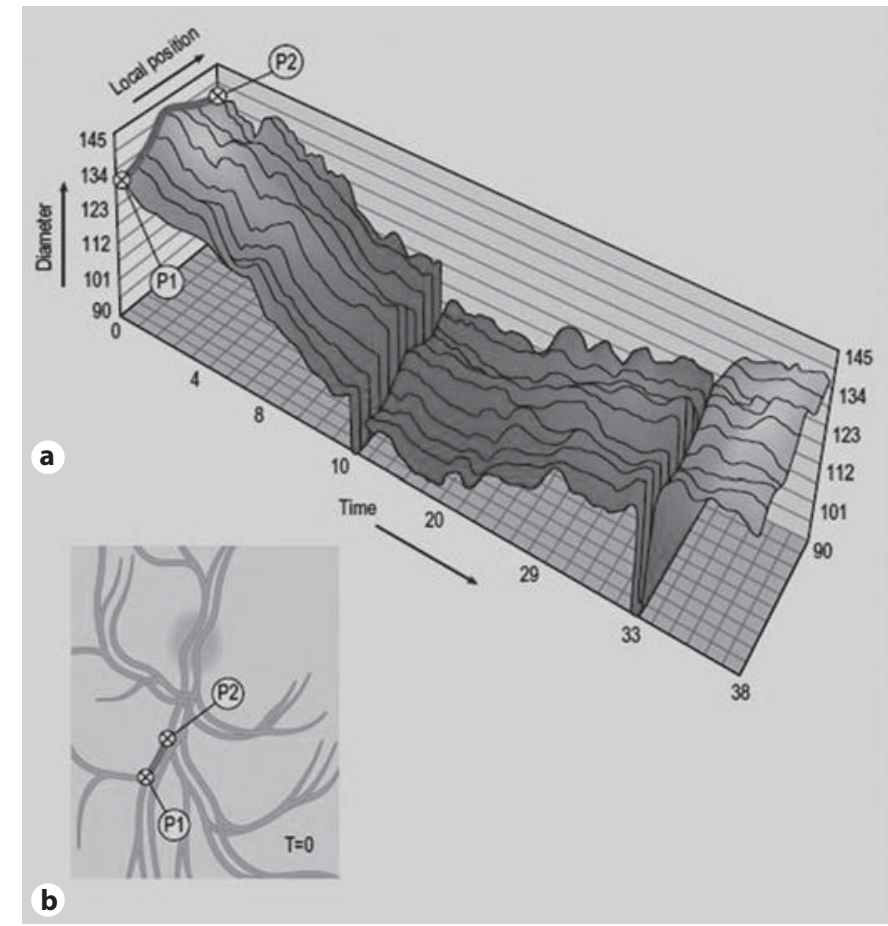

Fig. 1. a The RVA device consists of a retinal camera, a chargecoupled device (CCD)-measuring camera for electronic online image acquisition, and a computer for system control analysis and archiving of the $D$ data. In general, a vessel section of about 1.5 $\mathrm{mm}$ in length is scanned at a frequency of 25 images/s. b Time course variation of $D$ of a retinal vein measured by the RVA over a given vessel length from $\mathrm{P} 1$ to $\mathrm{P} 2$. Vein constriction is due to inhalation of $100 \%$ oxygen by the subject.

\section{Flicker Stimulation}

Following the first demonstration that $D$ of retinal vessels can be modulated by flickering the fundus illumination light [13] the use of the RVA has permitted the determination of the time course of the flicker-induced $D$ response and of the effect of varying the flicker frequency on this response [14].

There is now compelling evidence from studies in animals and human subjects that visual stimulation with flickering light increases retinal vessel diameter, retinal blood flow and optic nerve head (ONH) blood flow in humans [15]. Therefore, stimulation with flicker light has been used as a physiological provocation to investigate the regulation of vascular tone. Further investigations in a large number of subjects might generate new insight into the reliability of flicker data. This is important for the design and planning of future studies. 


\section{Clinical Use}

Measurements of $D$ are important, not only for scientific purposes, but also because several large-scale epidemiological studies have consistently reported the existence of a correlation between systemic disease factors and retinal vessel $D$. In particular, increased systemic blood pressure is reflected in the generalized arterial vasoconstriction of retinal vessels [16]. Thus, there is increasing evidence that changes in the retinal vessel $D$ not only carry information about the retinal circulation per se, but may also reflect systemic pathologies as such changes have been shown to predict risk for coronary heart disease, stroke and stroke mortality $[17,18]$. Pooled data from the Beaver Dam Eye Study and the Blue Mountains Eye Study also showed that smaller arterial $D$ and larger retinal venous $D$ are associated with increased risk for stroke mortality [19]. These data clearly support the suggestion that retinal vessel $D$ may serve as a predictor for events in other vascular beds, such as in the heart or brain.

It has been shown that changes in retinal vessel $D$ observed during systemic pathologies may be influenced by treatment. In particular, $D$ was found to be significantly reduced in diabetic patients who underwent laser treatment [20]. This finding has been interpreted as a sign for decreased blood flow due to better oxygenation of the photocoagulated tissue.

\section{Dye Dilution Technique}

The dye dilution technique allows the determination of $M C T$, i.e. the average time it takes for dye molecules, such a fluorescein injected into the circulation, to travel from the entry to the exit of a microvascular segment. The segment is assumed to have a single inflow (feeding artery) and a single outflow (draining vein). The passage of fluorescein through the artery and corresponding vein (arterial and venous dilution curves) is recorded by detecting photographically, photoelectrically, or by video the fluorescence intensity emitted by the dye, when the fundus is illuminated with light at wavelengths within the range of the excitation spectrum of fluorescein (blue). A barrier filter prevents excitation light from reaching the detection system. The dye dilution technique provides reliable data on MCT only if the vascular segment, the injected dye, the mode of recording of the dilution curves, and the correction for recirculation of the dye satisfy specific conditions [21-23]. In the application of this technique to the eye, particularly in cases of retinal vascular pathology (for instance, in proliferative retinopathy, diffusion of fluorescein from the retinal vessels may distort the dilution curves), the measured MCT must be regarded as an approximation of true MCT [24].

Using scanning laser ophthalmoscopy, additional parameters from the fluorescence intensity time course have been determined, such as the mean velocity of the dye in a retinal artery, which has been calculated from the appearance time of the dye front at two sites along a vessel and the distance between the sites, and the $A V P$, which is the time difference between a reference point at the temporal retinal artery and the first appearance in a vein adjacent to the artery [25]. In contrast to $M C T, A V P$ favors strongly the measurement of passage times of the dye through the shortest segment between an artery and a vein close to the papilla [24].

A study in monkeys, undertaken to determine the correlations between $M C T$ and $A V P$ and retinal $B F$, the latter measured by labeled microspheres, showed that these correlations were not statistically significant $(p>0.05)$ [26], even when the $M C T$ was calculated using an impulse response technique [27]. Clearly, $M C T$ and AVP data should not be interpreted in terms of $B F$.

\section{Velocity of Leukocytes}

The velocity of leukocytes $\left(V_{\text {leuk }}\right)$ has been measured by means of scanning laser ophthalmoscopy after tagging the cells with various dyes and tracking their motion in the retinal capillaries, veins and arteries on video images [28-32].

$V_{\text {leuk }}$ of leukocytes moving in perifoveal retinal capillaries (diameter 7-11 $\mu \mathrm{m}$ ) measured by scanning laser ophthalmoscopy was reported to be $1.4 \mathrm{~mm} / \mathrm{s}$ [31]. Using the blue-field simulation technique, which is based on the entoptic observation of one's own leukocytes moving in the macular area of the retina, it is possible to determine quantitatively the number $\left(N_{\text {leuk }}\right), V_{\text {leuk }}$, and $V_{\text {leuk }}$ pulsatility of these particles [33]. With this technique, subjects are asked to compare and match the global motion of a field of computer-simulated leukocytes displayed on a video monitor to the global motion of their own leukocytes by adjusting with potentiometers $N_{\text {leuk }}, V_{\text {leuk }}$, and $V_{\text {leuk }}$ pulsatility (variation of the speed during the cardiac cycle) of the simulated leukocytes [34]. Mean $V_{\text {leuk }}$ obtained under physiological conditions by various investigators ranged from 0.23 to 1.9 $\mu \mathrm{m} / \mathrm{s}$ [35-39]. The motion of these leukocytes is pulsatile in phase with the heartbeat, with an average $V_{\text {leuk, systole }} / V_{\text {leuk, diastole }}$ of 2.8 [33].

Visual acuity must be better than $20 / 50$ for a reliable measurement [40]. The ability of a subject to do the bluefield simulation test can be assessed by having subjects 


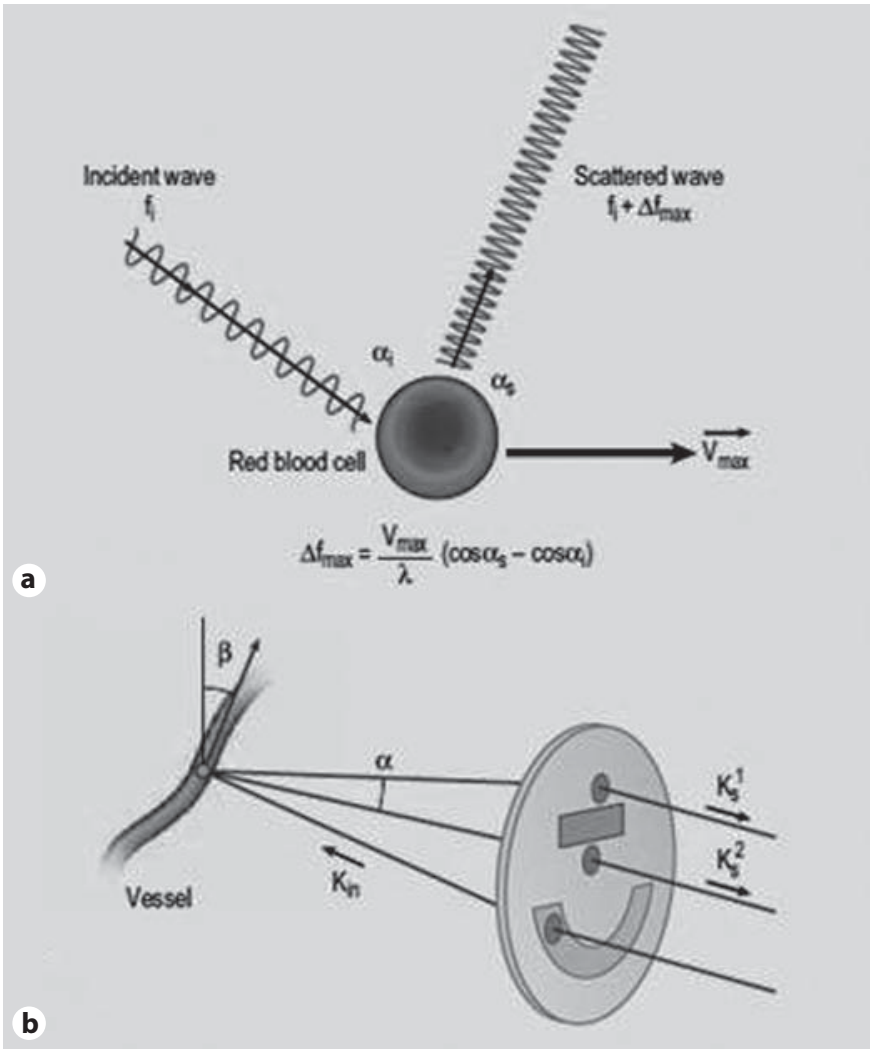

Fig. 2. a Doppler effect. The frequency of laser light scattered by an RBC (moving at speed $V_{\max }$ ) is shifted by an amount $\Delta f_{\max }$ compared to the frequency of the light incident $\left(f_{i}\right)$ on the RBC. $\alpha_{i}$ and $\alpha_{s}$ are the angles between $\mathrm{V}_{\max }$ and the directions of the incident and scattered light, respectively. $\lambda$ is the wavelength of the incident light [with permission from ref. 42]. b Principle of bidirectional LDV (BLDV). Laser light scattered from the RBCs is detected along two directions: $K_{s}^{1}$ and $K_{s}^{2}$ (angle $\alpha$ between them). $\beta$ is the angle between the plane of the vessel at the site of measurement and the direction of the velocity. $V_{\max }$, the centerline velocity of the RBCs, is determined from the maximum shifts in the Doppler shift power spectrum obtained in each scattering direction and the geometrical scattering parameters. The measurement is independent from the direction of the incident light defined by $K_{\text {in }}$ [with permission from ref. 43].

match the speed and number of two simulated leukocyte motions displayed on computer screens. Blue-field data have been confirmed by the objective scanning laser ophthalmoscope-adaptive optics imaging technique [41].

\section{Bidirectional Laser Doppler Velocimetry}

BLDV allows the measurement of absolute blood velocity. BLDV is based on the Doppler effect (fig. 2) [42]. Retinal $B F$ (in $\mu \mathrm{l} / \mathrm{min}$ ) in the main retinal vessels is calculated from the centerline velocity $\left(V_{\max }\right)$ of RBCs [43].

$$
V(d)=V_{\max }\left[1-\frac{\left|d-d_{o}\right|^{K}}{R_{l}}\right]
$$

Fig. 3. Central velocity $\left(V_{\max }\right)$ of RBCs (proportional to cutoff frequency of Doppler shift power spectrum) in a retinal artery (diameter, $100 \mu \mathrm{m}) . \mathrm{V}(d)$ is the velocity at distance $(d)$ from the inner wall, $d_{0}$ the position of the vessel center. $K$ is 2.38 in the systolic, 1.94 in the diastolic phase [from ref. 47, with permission].

The measurement is independent of the direction of the incident light defined by $\mathrm{K}_{\mathrm{in}}$ (fig. 2) $[43,44]$. Combined with $D$ measurements of these vessels mean $B F$ is calculated as $\pi \times D^{2} \times V_{\text {mean }} / 4$. $V_{\text {mean }}$ represents an average of the RBC velocities over the vessel cross section. For a parabolic velocity profile (see below), $V_{\text {mean }}=V_{\text {max }} / 2$. The average $\mathrm{RBC}$ velocity during the heart cycle is obtained by integrating $V_{\text {mean }}$ over this cycle.

In straight portions of the first-order retinal arteries and veins of the human eye, the velocity profile of RBCs does not differ significantly from the parabolic shape during both systole and diastole (fig. 4) [45-48]. Deviations from the parabolic profile increase, however, with the diminution of the diameter of the vessels and a correction factor in the formula given in figure 3 is needed to improve the fit $[47,49]$. At retinal arterial branchings and venous junctions marked deviations from the parabolic profile are expected, as illustrated by measurements using the techniques of confocal scanning laser Doppler velocimetry (fig. 4) [47].

Averaged over the cardiac cycle, $V_{\text {max }}$ ranges from approximately 7 to $35 \mathrm{~mm} / \mathrm{s}$ in arteries with a $D$ between 40 and $130 \mu \mathrm{m}$ and from 5 to $25 \mathrm{~mm} / \mathrm{s}$ in veins with a $D$ between 60 and $180 \mu \mathrm{m}$ [50-52]. Similar values were found in the primate retina with the targeted dye delivery technique $[53,54]$. In normal human and primate monkey eyes, $V_{\text {max }}$ increases linearly with $D$, as found in most vascular beds [50, 54].

Retinal $B F$ represents only about $4 \%$ of total ocular $B F$ [55]. In humans, recent measurements of total retinal $B F$ (40.8-52.9 $\mu \mathrm{l} / \mathrm{min}$ ) using Fourier-Domain OCT (FDOCT) [56] are in the range of values obtained by BLDV [50]. Retinal $B F$ calculated from BLDV is larger in the temporal human retina than in the nasal region, supposedly due to the larger size (by 20-25\%) and higher meta- 


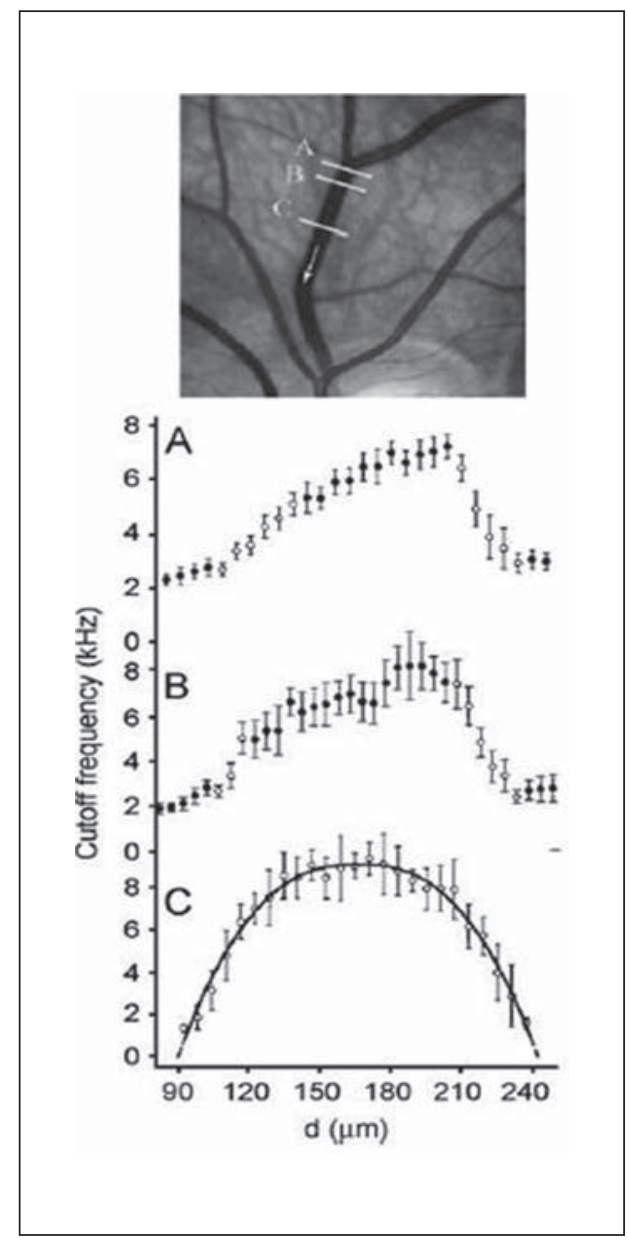

Fig. 4. Velocity profiles of RBCs in a retinal vein downstream of a venular junction. At a distance of about one (A) and two (B) vessel diameters from the junction, the velocity profiles are asymmetric. At 5 diameters downstream from the junction (C), the profile is symmetric, although still significantly blunted. Data collected in the systolic (closed circles) and diastolic (open circles) phase of the cardiac cycle. The continuous line $(\mathrm{C})$ is the fit according to the equation given in figure 3 , with $\mathrm{K}=2.38 \pm 0.5$ in the systolic and $1.94 \pm 0.80$ (95\% CI) in the diastolic phase, respectively [from ref. 47 , with permission].

bolic rate of the former. $B F$ values in the superior and inferior hemispheres were found to be similar. In contrast, $B F$ in the superior retinal hemisphere does not appear to differ from $B F$ in the inferior hemisphere $[50,57-$ 59]. This pertains also to $B F$ in the superior and inferior parts of the macular region [60].

In normal subjects, $B F$ differs between studies, with values between 30 and $46 \mu \mathrm{l} / \mathrm{min}[50,52,56,61,62]$ and 65-80 $\mathrm{ml} / \mathrm{min}[57,59,63]$. By comparison, the microsphere injection technique provided volumetric flow rates of 25 and $34 \mu \mathrm{l} / \mathrm{min}$ for the macaque monkey and $50 \pm 39 \mu \mathrm{l} / \mathrm{min}$ for the rhesus monkey $[64,65]$.

A stabilized retinal laser Doppler instrument adapted to a fundus camera achieved excellent reproducibility of results and $B F$ measurements in units of microliters per minute, indicating that the instrument can be used for reliable comparison of blood flow characteristics at different retinal vascular sites in the same eye, at comparable sites in both eyes, and for comparison between patients and healthy control subjects [66].

\section{Doppler FD-OCT}

OCT provides high-resolution cross-sectional imaging and is commonly used in the diagnosis and management of retinal diseases. In addition to obtaining morphological images, OCT can also detect the Doppler shift of reflected light, which provides information on threedimensional distribution of the axial velocity component of blood in retinal vessels $[67,68]$. For Doppler FD-OCT $[69,70]$ light reflected by moving blood induces a Doppler frequency shift that is proportional to the velocity component parallel to the axis of the probing beam. This frequency shift introduces a phase shift in the spectral interference pattern that is captured by a line camera. The spectral information is converted into complex axial scans containing both amplitude and phase, using the fast Fourier transform. The phase differences between sequential axial scans at each pixel are calculated to determine the Doppler shift. In vivo flow measurements in branch retinal vessels have been reported using Doppler FD-OCT [71, 72].

Doppler FD-OCT combined with a double circular scan pattern around the optic disk to rapidly measure total retinal $B F$ has been used in a group of normal human subjects [56]. Four pairs of circular scans that transected all retinal branch vessels were completed in $2 \mathrm{~s}$. Total retinal $B F$ was obtained by summing the flows in the branch veins. Total retinal $B F$ could be measured in 8 of 10 subjects: mean $(\mathrm{SD})=45.6(3.8) \mu \mathrm{l} / \mathrm{min}$ (range 40.8-52.9 $\mu \mathrm{l} /$ $\mathrm{min}$ ). The coefficient of variation for repeated measurements was $10.5 \%$. These flow values are within the range previously established by laser Doppler velocimetry combined with $D$ measurements [56].

\section{Laser Doppler Flowmetry}

In a tissue, such as the optic disk, $B F$ can be measured by using LDF [73]. Two measurement modes have been implemented: In the first mode, a laser beam is focused onto the tissue and the light scattered from this tissue is detected to obtain the Doppler shift power spectrum re- 


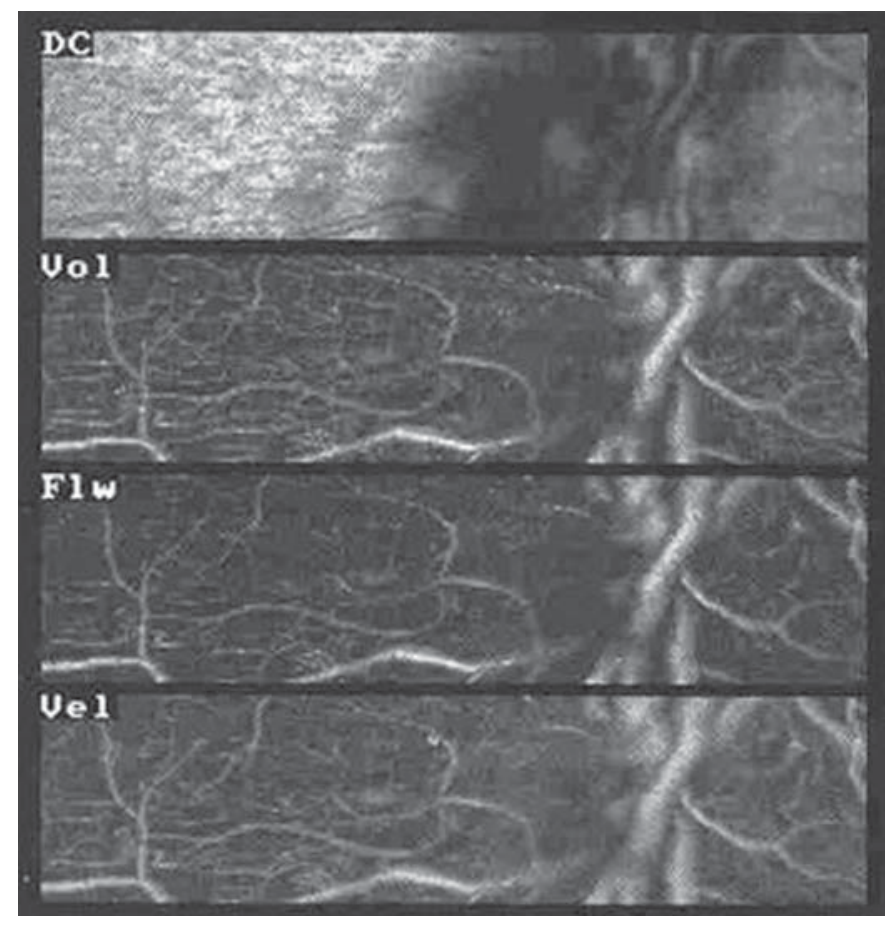

Fig. 5. Perfusion maps obtained from the $\mathrm{ONH}$ and temporal retina of a normal eye. From top to bottom: reflectance image, volume map, flow map, velocity map. The perfusion maps are colorcoded; light colors show high perfusion values [from ref. 79, with permission].

sulting from the motion of RBCs. Applying the theory of Bonner and Nossal [74], the following flow parameters are derived from the Doppler shift power spectrum: Vel, the mean speed of the RBCs moving in the sampling volume, $V o l$, the number of moving RBCs and $B F=k \times V e l$ $\times \mathrm{Vol}$, the total flux of RBCs in this volume. Vel is expressed in Hertz, and $\mathrm{Vol}$ and $F$ in arbitrary units; $k$ is a constant of proportionality. With the second mode, scanning the laser beam across a two-dimensional area of the fundus provides an image of the RBC flux in the capillaries of the optic disk and peripapillary retina, as well as an intensity image of the perfused retinal vessels [75] (fig. 5).

\section{Laser Speckle Flowgraphy}

The temporal variations of laser speckle resulting from the interference of laser waves scattered by the tissue can be used to determine the velocity of RBCs in the $\mathrm{ONH}$, retinal and choroidal circulations [76, 77]. This laser speckle flowgraphy and the LDF approaches are different ways of looking at the same phenomenon. Both techniques measure at a single point in the tissue. In both cases, adding scanning provides a map of the spatial velocity and flux $[78,79]$.

One important point when applying these laser-based techniques is that the measured flux depends on the scattering and optical absorption properties of the tissue. Therefore, direct comparison between flux values from different eyes may not be valid due to variations in the scattering properties resulting from differences in tissue structure and composition [80, 81]. Furthermore, for a valid comparison between flux values obtained at different times in the same eye by dynamic and scanning LDF and laser speckle flowgraphy, the tissue must be assumed to maintain the same scattering properties over time, which may not be the case during the development of various pathologies.

\section{Color Doppler Imaging}

Color Doppler imaging for retrobulbar vessels is an ultrasound technique that combines B-scan imaging of tissue structure, color representation of blood flow based on Doppler-shifted frequencies, and pulse-Doppler measurements of blood velocities. The flow parameters measured are the peak-systolic velocity (PSV), the enddiastolic velocity $(E D V)$, and the resistivity index $R I=$ $(P S V-E D V) / P S V$ [82]. The application of color Doppler imaging to ophthalmology has provided data on central retinal arterial $P S V$ and $E D V$ [83]. A nonexhaustive review of the literature between 1991 and 2006 reveals that the average $P S V$ and $E D V$ values in normal subjects range from about 6 to 20 and 1.7 to $10 \mathrm{~cm} / \mathrm{s}$, respectively $[24,84]$.

\section{Modifications of Retinal Blood Flow in Ischemic Microangiopathies}

\section{Branch Retinal Vein Occlusion}

Branch retinal vein occlusion (BRVO) most commonly occurs at an arteriovenous crossing where arteries and veins are bound together in a common adventitia. As a consequence, arteriosclerotic changes can disturb $B F$ in the venule, damage the endothelial cells and leading to thrombus formation $[85,86]$. Clinical and angiographic findings have confirmed disturbances of venous $B F$ and, exceptionally, reveal complete flow interruption. The importance of measuring retinal $B F$ in retinal venous occlusions as an indicator of the severity of microcirculatory disorders has been discussed. In particular, blood velocity appears to provide an important criterion for the assessment of the stasis conditions and the diameter of the vessels offers essential information on local regulative 
processes [87-89]. Decreased [90] or retrograde [91] BF into the arterioles, as well as blood flowing from the venules into the capillaries [92], were observed in monkey and cat models of BRVO, respectively. In humans, pulsatile venular outflow and reverse $B F$ in arterioles during diastole have been observed with videoangiography [93]. Scanning LDF has documented a decreased $B F$ in retinal capillary areas affected by BRVO [94].

In experimental BRVO, a decline of preretinal nitric oxide by $75 \%$ down to $25 \%$ of its baseline value was observed at $2 \mathrm{~h}$ post-occlusion. It occurred simultaneously with a decrease of the arteriolar $D$ in the affected territory [95]. Such arteriolar constriction could be reversed by addition of nitric oxide donors [96], confirming that BRVO impairs the retinal nitric oxide-producing metabolic process responsible for the maintenance of the vascular tone [97].

Endothelium-driven myogenic vasoconstriction, related to the increased pressure within an occluded venule and the resulting increase in transmural pressure in the arterioles irrigating areas affected by BRVO [98], represents an additional mechanism involved in the arteriolar vasoconstriction. The resulting arteriolar vasoconstriction is probably mediated by the endothelium through interactions between ET-1 and ETA receptor. In patients with ischemic BRVO, ET-1 plasma concentrations are increased. This situation may aggravate vasoconstriction of the retinal arterioles, thus exacerbating ischemia [99, 100]. A significant increase in retinal arteriolar $D$ was demonstrated after juxta-arteriolar endothelin A receptor inhibitor BQ-123 microinjection in healthy and in acute $\mathrm{BRVO}$ minipig retinas. The results suggest a role for endothelin-1 in maintaining retinal basal arteriolar tone. Reversing the BRVO-related vasoconstriction by juxtaarteriolar BQ-123 microinjection could bring a new perspective to the management of BRVO [101].

\section{Diabetic Microangiopathy}

The hypothesis that altered retinal $B F$ plays a role in the development of diabetic retinopathy (DR) was made more than 25 years ago [102]. It has since led to numerous investigations of $B F$ in the various tissues of the eye in this disease aimed at getting some insight into the progression of DR. At present this knowledge is rather controversial since some of the observations appear to be contradictory $[103,104]$. Discrepancies in the findings may be due to differences in the type of patients, i.e. type I versus type II diabetes, controlled versus poorly controlled diabetes, improvement in the degree of glucose control over the years, short versus long duration of the disease, and presence or absence of other concomitant diseases, such as systemic hypertension [105]. Increased $D$ of the retinal arterioles and veins is seen early in the disease $[105,106]$. On the other hand, retinal $B F$ seems to be unaffected in eyes with well-regulated diabetes until more severe retinopathy develops [106-108]. In patients with proliferative $D R$, retinal hemodynamics seem to depend on the specific pathologic features. For example, reduced retinal $B F$ and vessel staining seem to be associated with severe capillary nonperfusion [109].

\section{Dysregulation of Retinal BF in Diabetes}

Numerous studies have shown that damage to the vascular wall along with impaired rheological properties of blood may affect the ability of the diabetic retina to regulate its $B F$.

\section{Hypoxia}

In patients with nonproliferative DR, isocapnic hypoxia induces a significant increase in $V_{\text {leuk }}$ in the perifoveal circulation, whereas $D$ of retinal vessels remains unchanged. Patients with proliferative DR show a nonsignificant change in both parameters, indicating that $B F$ regulation in response to a hypoxic challenge is blunted in proliferative DR, consequent of the hypoxic retinal conditions. After laser treatment inducing restoration of the retinal oxygenation, $V_{\text {leuk }}$ and vessel $D$ significantly increase in response to hypoxia [110].

\section{Hyperoxia}

Early studies have revealed a blunted hyperoxia-induced vasoconstriction of the vessels branching from the central retinal artery in diabetic patients [111]. Hyperoxia induces a retinal $B F$ decrease by $61 \%$ in healthy individuals, $53 \%$ in diabetic patients without overt DR, $38 \%$ in patients with background DR, and $24 \%$ in patients with proliferative DR [112]. Most diabetic patients have a blunted retinal $B F$ response to increases in oxygen concentration in inhaled air, which has been attributed to the presence of chronic retinal hypoxia $[105,107]$. Alternatively, this blunted response could result from an increased production of endothelin-1 [113], a mediator of the hyperoxia-induced retinal $B F$ response. The constriction of the vessel $D$ is attenuated in patients with proliferative DR [114]. In patients with proliferative DR, panretinal photocoagulation almost restored the hyperoxiainduced $B F$ response to normal values as this stimulus resulted in a $54 \%$ decrease in retinal BF particularly in those who also showed regression of neovascularization [115]. 
Smoking significantly alters the reactivity of retinal $B F$ to hyperoxia and almost abolishes the autoregulatory vasoconstriction in diabetic patients [116]. Similarly, eyes with either nonproliferative or proliferative DR showed, during hyperoxia, a significantly decreased $V_{\text {leuk }}$ in the perifoveal capillaries. After photocoagulation, the decrease in $V_{\text {leuk }}$ observed during hyperoxia was no longer significant, suggesting a reduced response in retinal capillary $B F$ [110].

\section{Glycemia}

Glycemia may affect retinal $B F$ [104]. $A V P$ is positively correlated with hemoglobin $A_{1 c}$ in adults with type I and type II diabetes $[117,118]$. According to a number of studies, retinal $B F$ markedly increases when blood glucose is acutely elevated [119-122], as a result of an increase in retinal oxygen consumption during hyperglycemia [123]. Additional finding failed to confirm any changes of $B F$ velocity in macular capillaries and retinal vessel $D$ following glucose infusion, neither in healthy controls nor in diabetic patients [124] nor during the postprandial phase $[108,125]$. Strict diabetic control by intensified insulin therapy is ambiguous, since soon after its introduction, a number of patients showed marked progression of DR [126-128]. A blue-field study demonstrated that leukocyte flux, calculated as the product of $V_{\text {leuk }} \times N_{\text {leuk }}$, was significantly bigger in eyes that showed progression of retinopathy than in eyes that did not [129]. This suggests a relationship between progression of $\mathrm{DR}$ and the failure of retinal $B F$ to decrease within days after institution of strict diabetic control [129-131]. The ocular hyperperfusion following the onset of intensified insulin therapy is inversely correlated with the plasma concentration of ET-1 in type I diabetes, suggesting that ET-1 levels affect ocular perfusion [132].

\section{BF Response to Changes of Ocular Perfusion Pressure and to Flicker Stimulation}

The ability of the retinal circulation to respond to changes in ocular $P P$ is altered in diabetes [133], regardless of whether the pressure is decreased through an increase in IOP, by treatment with tyramine [134] or by systemic sympathetic stimulation induced by isometric exercise [135-137] (fig. 6). This alteration is further accentuated by hyperglycemia [134] and more prevalent in patients with autonomic dysfunction than in those with an intact autonomic nervous system [138]. The myogenic constriction of the arterial wall in human retinal arterioles is significantly improved as a rise in blood pressure of $19.5 \pm 9.9 \mathrm{~mm} \mathrm{Hg}$ during improved metabolic control

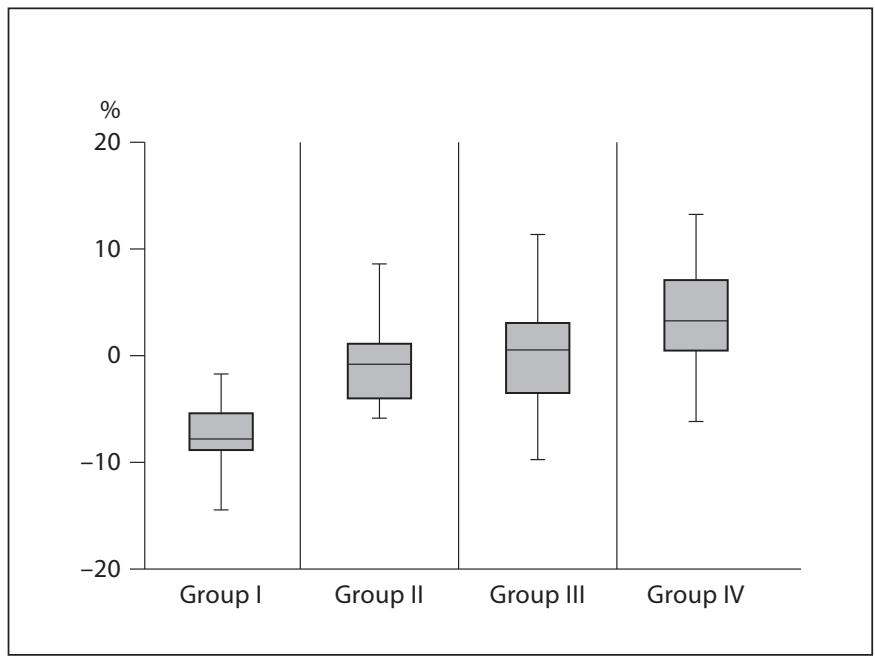

Fig. 6. Measurements of the myogenic response of retinal arterioles using the RVA during isometric exercise in subjects with different stages of DR. Group I: no DR, group II: mild/moderate DR, group III: moderate/severe nonproliferative DR with laser treatment, and group IV: proliferative DR with laser treatment. A similar blood pressure (BP) rise was achieved in all subjects. In response to this BP rise, group I demonstrated a vasoconstriction of $-7.6 \%$ ( \pm 4.1$)$. In groups III and IV, respectively, an abnormal vasodilation of $+0.44 \%( \pm 5.9)$ and of $+3.2 \%( \pm 5.9)$ was found [from ref. 137, with permission].

is associated with a significantly improved arterial vasoconstriction from $-3.2 \pm 2.9$ to $-5.9 \pm 2.7 \%$ [137].

The response of $D$ of retinal vessels to diffuse luminance flicker is blunted in insulin-dependent diabetic patients in comparison to healthy controls $[139,140]$ (fig. 7), either due to a vascular abnormality (endothelial dysfunction or loss of pericytes) and/or decreased neural activity response resulting from selective abnormalities of Müller glial cell function [141]. These cells probably play an important role in the coupling between retinal neural activity and $B F$ [15]. The blunting occurs already in patients without DR and increases with the stage of DR [142].

\section{Dysregulation of Retinal BF in Glaucoma}

The role of vascular disturbances in the pathogenesis of glaucoma remains controversial, but most experts agree that elevated IOP alone does not explain the whole spectrum of individuals with open-angle glaucoma. Apart from IOP, a variety of other systemic and ocular risk factors for glaucoma have been identified, such as heart disease [143], low systolic blood pressure and low ocular perfusion pressure [144]. A large number of stud- 


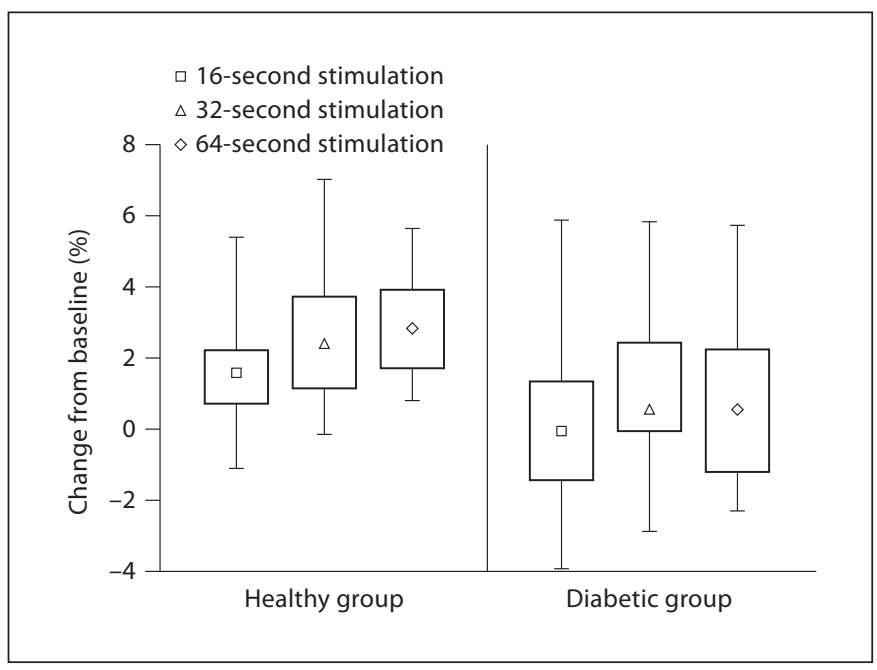

Fig. 7. Flicker-induced $D$ responses of retinal arteries are abnormally reduced in patients with insulin-dependent diabetes mellitus with no or mild nonproliferative retinopathy. Box (mean, 25 and $75 \% \mathrm{CI}$ ) and whisker (5 and 95\% CI) plot of $D$ responses (percentage changes) as recorded after 16, 32, and 64 s of flicker stimulation [from ref. 139, with permission].

ies, using different clinical techniques, have demonstrated reduced $\mathrm{ONH} B F$ in eyes with glaucoma when compared to normal eyes. Whether this is secondary to loss of neural tissue or a causative factor, however, is not known. As $B F$ through the retina and the $\mathrm{ONH}$ is efficiently autoregulated, moderate increments in IOP would have no or little effect on $B F$ through these tissues. The situation may be different in the presence of deficient ocular $B F$, and $B F$ autoregulation could then be affected even by small increments in IOP. An impaired autoregulation of the retinal circulation was indeed found in eyes with glaucoma with the blue-field simulation technique [145]. This investigation determined the maximum, acutely increased IOP above resting IOP at which $V_{\text {leuk }}$ is maintained constant by autoregulation. This maximum IOP was $25 \pm 1.5 \mathrm{~mm} \mathrm{Hg}( \pm 1 \mathrm{SD})$ for patients with primary open-angle glaucoma and $30 \pm 3.6 \mathrm{~mm} \mathrm{Hg}$ in normal subjects. Studies with other techniques have also suggested that autoregulation of retinal and/or ONH $B F$ is reduced in eyes with glaucoma. Thus retinal venous $D$ response to short-term elevations in IOP was found to be altered [9] and changes in rim perfusion after a therapeutic IOP reduction [146] suggest that autoregulation may be defective in eyes with glaucoma while intact in ocular hypertension. Also the increase in ONH BF [147] and $D$ of retinal veins [148] in response to flicker were found to be significantly diminished in glaucoma patients as compared with healthy volunteers, both results being indicative of an impairment of neurally mediated vasoreactivity.

\section{Disclosure Statement}

Both authors confirm to disclose any sponsorship or funding arrangements related to their research and any possible conflicts of interest.

\section{References}

$\checkmark 1$ Hickam JB, Frayser R: Studies of the retinal circulation in man: observation on vessel diameter, arteriovenous oxygen difference and mean circulation time. Circulation 1966;33: 302-316.

$\checkmark 2$ Murray CD: The physiological principle of minimum work. I. The vascular system and the cost of blood volume. Proc Natl Acad Sci USA 1926;12:207-214.

3 LaBarbera M: The design of fluid transport systems: a comparative perspective; in Bevan JA, Kaley G, Rubanyi GM (eds): Flow-Dependent Regulation of Vascular Function. New York, Oxford University Press, 1995.

4 Glucksberg MR, Dunn R: Direct measurement of retinal microvascular pressures in the live, anesthetized cat. Microvasc Res 1993;45:158-165.
5 Stoltz JF, Donner M: New trends in clinical hemorheology: an introduction to the concept of the hemorheological profile. Schweiz Med Wochenschr Suppl 1991;43:41-49.

-6 Knabben HWS, Remky A, Schulte K, Arend $\mathrm{O}$, Reim M: Retinal hemodynamics in patients with hyperviscosity syndrome. Klin Monatsbl Augenheilkd 1995;206:152-156.

$\checkmark 7$ Delori FC, Fitch KA, Feke GT, Deupree DM, Weiter JJ: Evaluation of micrometric and microdensitometric methods for measuring the width of retinal vessel images on fundus photographs. Graefes Arch Clin Exp Ophthalmol 1988;226:393-399.

8 Rassam SM, Patel V, Brinchmann-Hansen O, Engvold O, Kohner EM: Accurate vessel width measurement from fundus photographs: a new concept. Br J Ophthalmol 1994;78:24-29.
9 Nagel E, Munch K, Vilser W: Measurement of the diameter of segments of retinal branch vessels in digital fundus images: an experimental study of the method and reproducibility. Klin Monatsbl Augenheilkd 2001;218: 616-620.

10 Pache M, Nagel E, Flammer J: Reproducibility of measurements with the retinal vessel analyzer under optimal conditions. Klin Monatsbl Augenheilkd 2002;219:523-527.

11 Polak K, Dorner G, Kiss B, Polska E, Findl O, Rainer G, Eichler HG, Schmetterer L: Evaluation of the Zeiss retinal vessel analyser. Br J Ophthalmol 2000;84:1285-1290.

12 Seifertl BU, Vilser W: Retinal Vessel Analyzer (RVA) - design and function. Biomed Tech (Berl) 2002;47(suppl 1):678-681. 
13 Formaz F, Riva CE, Geiser MH: Diffuse luminance flicker increases retinal vessel diameter in humans. Curr Eye Res 1997;16: 1252-1257.

14 Polak K, Schmetterer L, Riva CE: Influence of flicker frequency on flicker-induced changes of retinal vessel diameter. Invest Ophthalmol Vis Sci 2002;43:2721-2726.

$\checkmark 15$ Riva CE, Logean E, Falsini B: Visually evoked hemodynamical response and assessment of neurovascular coupling in the optic nerve and retina. Prog Retin Eye Res 2005;24:183-215.

16 Wong TY, Mitchell P: The eye in hypertension. Lancet 2007;369:425-435.

$\checkmark 17$ Wong TY, Klein R, Couper DJ, Cooper LS, Shahar E, Hubbard LD, Wofford MR, Sharrett AR: Retinal microvascular abnormalities and incident stroke: the Atherosclerosis Risk in Communities Study. Lancet 2001; 358:1134-1140.

18 Wong TY, Klein R, Sharrett AR, Duncan BB, Couper DJ, Tielsch JM, Klein BE, Hubbard LD: Retinal arteriolar narrowing and risk of coronary heart disease in men and women. The Atherosclerosis Risk in Communities Study. JAMA 2002;287:1153-1159.

19 Wang JJ, Liew G, Klein R, Rochtchina E, Knudtson MD, Klein BE, Wong TY, Burlutsky G, Mitchell P: Retinal vessel diameter and cardiovascular mortality: pooled data analysis from two older populations. Eur Heart J 2007;28:1984-1992.

-20 Mendrinos E, Mangioris G, Papadopoulou DN, Dosso AA, Pournaras CJ: Retinal vessel analyzer measurements of the effect of panretinal photocoagulation on the retinal arteriolar diameter in diabetic retinopathy. Retina 2010;30:555-561.

21 Meier P, Zierler KL: On the theory of the indicator-dilution method for measurement of blood flow and volume. J Appl Physiol 1954; 6:731-744.

22 Gonzalez-Fernandez JM: Theory of the measurement of the dispersion of an indicator in indicator-dilution studies. Circ Res 1962;10: 409-428.

-23 Riva CE, Feke GT, Ben-Sira I: Fluorescein dye-dilution technique and retinal circulation. Am J Physiol 1978;234:H315-H322.

24 Riva CE, Alm A, Pournaras CJ: Ocular circulation; in Levin LA, Nilsson SFE, VerHoeve J, Wu S, Kaufman PL, Alm A (eds): Adler's Physiology of the Eye, ed 11. New York, Elsevier, 2011.

25 Wolf S, Jung F, Kiesewetter H, Korber N, Reim M: Video fluorescein angiography: method and clinical application. Graefes Arch Clin Exp Ophthalmol 1989;227:145-151.

-26 Tomic L, Maepea O, Sperber GO, Alm A: Comparison of retinal transit times and retinal blood flow: a study in monkeys. Invest Ophthalmol Vis Sci 2001;42:752-755.

-27 Sperber GO, Alm A: Retinal mean transit time determined with an impulse-response analysis form video fluorescein angiograms. Acta Ophthalmol Scand 1997;75:532-536.
28 Nishiwaki H, Ogura Y, Kimura H, Kiryu J, Honda Y: Quantitative evaluation of leukocyte dynamics in retinal microcirculation. Invest Ophthalmol Vis Sci 1995;36:123-130.

29 Matsuda N, Ogura Y, Nishiwaki H, Miyamoto K, Matsubara T, Kiryu J, Honda Y: Visualization of leukocyte dynamics in the choroid with indocyanine green. Invest Ophthalmol Vis Sci 1996;37:2228-2233.

30 Le Gargasson JF, Paques M, Guez JE, Boval B, Vicaut E, Hou X, Grall Y, Gaudric A: Scanning laser ophthalmoscope imaging of fluorescein-labelled blood cells. Graefes Arch Clin Exp Ophthalmol 1997;235:56-58.

31 Yang Y, Kim S, Kim J: Fluorescent dots in fluorescein angiography and fluorescein leukocyte angiography using a scanning laser ophthalmoscope in humans. Ophthalmology 1997;104:1670-1676.

32 Hossain P, Liversidge J, Cree MJ, Manivannan A, Vieira P, Sharp PF, Brown GC, Forrester JV: In vivo cell tracking by scanning laser ophthalmoscopy: quantification of leukocyte kinetics. Invest Ophthalmol Vis Sci 1998;39:1879-1887.

33 Riva CE, Petrig B: Blue field entoptic phenomenon and blood velocity in the retinal capillaries. J Opt Soc Am 1980;70:12341238.

34 Riva CE, Petrig BL: Retinal blood flow: laser Doppler velocimetry and blue field simulation technique; in Masters BR (ed): Noninvasive Diagnostic Techniques in Ophthalmology. New York, Springer, 1990, pp 390-409.

-35 Fallon TJ, Maxwell D, Kohner EM: Measurement of autoregulation of retinal blood flow using the blue field entoptic phenomenon. Trans Ophthalmol Soc UK 1985;104:857860.

36 Robinson F, Petrig BL, Sinclair SH, Riva CE, Grunwald JE: Does topical phenylephrine, tropicamide, or proparacaine affect macular blood flow? Ophthalmology 1985;92:11301132 .

37 Lofti K, Grunwald JE: The effect of caffeine on the human macular circulation. Invest Ophthalmol Vis Sci 1991;32:3028-3032.

38 Fuchsjager-Mayrl G, Malec M, Polska E, Jilma B, Wolzt M, Schmetterer L: Effects of granulocyte colony stimulating factor on retinal leukocyte and erythrocyte flux in the human retina. Invest Ophthalmol Vis Sci 2002;43:1520-1524.

39 Loukovaara S, Harju M, Kaaja R, Immonen I: Retinal capillary blood flow in diabetic and nondiabetic women during pregnancy and postpartum period. Invest Ophthalmol Vis Sci 2003;44:1486-1491.

40 Loebl M, Riva CE: Macular circulation and the flying corpuscles phenomenon. Ophthalmology 1978;85:911-917.

41 Martin JA, Roorda A: Direct and noninvasive assessment of parafoveal capillary leukocyte velocity. Ophthalmology 2005;112: 2219-2224.
42 Riva CE, Petrig BL: Laser Doppler techniques in ophthalmology: principles and applications; in Fankhauser F, Kwasniewska S (eds): Lasers in Ophthalmology - Basic, Diagnostic and Surgical Aspects. The Hague, Kugler 2003, pp 51-59.

43 Riva CE, Grunwald JE, Sinclair SH, O’Keefe K: Fundus camera based retinal LDV. Appl Opt 1981;20:117-120.

44 Riva CE, Feke GT, Eberli B, Benary V: Bidirectional LDV system for absolute measurement of blood speed in retinal vessels. Appl Opt 1979;18:2301-2306.

45 Yazdanfar S, Rollins AM, Izatt JA: Imaging and velocimetry of the human retinal circulation with color Doppler optical coherence tomography. Opt Lett 2000;25:1448-1450.

-46 Leitgeb RA, Schmetterer L, Drexler W, Fercher AF: Real-time assessment of retinal blood flow with ultrafast acquisition by color Doppler Fourier domain optical coherence tomography. Opt Express 2003;11:31163121.

47 Logean E, Schmetterer L, Riva CE: Velocity profile of red blood cells in human retinal vessels using confocal scanning laser Doppler velocimetry. Laser Physics 2003;13:4551.

48 Yazdanfar S, Rollins AM, Izatt JA: In vivo imaging of human retinal flow dynamics by color Doppler optical coherence tomography. Arch Ophthalmol 2003;121:235-239.

49 Zhong Z, Song H, Chui TY, Petrig BL, Burns SA: Noninvasive measurements and analysis of blood velocity profiles in human retinal vessels. Invest Ophthalmol Vis Sci 2011;52: 4151-4157.

50 Riva CE, Grunwald JE, Sinclair SH, Petrig BL: Blood velocity and volumetric flow rate in human retinal vessels. Invest Ophthalmol Vis Sci 1985;26:1124-1132.

-51 Feke GT, Goger DG, Tagawa H, Delori FC: Laser Doppler technique for absolute measurement of blood speed in retinal vessels. IEEE Trans Biomed Eng 1987;34:673-680.

52 Grunwald JE, Riva CE, Baine J, Brucker AJ: Total retinal volumetric blood flow rate in diabetic patients with poor glycemic control. Invest Ophthalmol Vis Sci 1992;33: 356-363.

53 Khoobehi B, Peyman GA, Niesman MR, Oncel M: Measurement of retinal blood velocity and flow rate in primates using a liposome dye system. Ophthalmology 1989;96:905912.

54 Guran T, Zeimer RC, Shahidi M, Mori MT: Quantitative analysis of retinal hemodynamics using targeted dye delivery. Invest Ophthalmol Vis Sci 1990;31:2300-2306.

55 Alm A: Ocular circulation; in Hart W (ed): Adler's Physiology of the Eye. St Louis, Mosby-Year Book, 1992, pp 198-227.

56 Wang Y, Lu A, Gil-Flamer J, Tan O, Izatt JA, Huang D: Measurement of total blood flow in the normal human retina using Doppler Fourier-domain optical coherence tomography. Br J Ophthalmol 2009;93:634-637. 
57 Feke GT, Tagawa H, Deupree DM, Goger DG, Sebag J, Weiter JJ: Blood flow in the normal human retina. Invest Ophthalmol Vis Sci 1989;30:58-65.

58 Rassam SM, Patel V, Chen HC, Kohner EM: Regional retinal blood flow and vascular autoregulation. Eye 1996;10:331-337.

-59 Garcia JPS Jr, Garcia PT, Rosen RB: Retinal blood flow in the normal human eye using the canon laser blood flowmeter. Ophthalmic Res 2002;34:295-299.

-60 Kimura I, Shinoda K, Tanino T, Ohtake Y, Mashima Y, Oguchi Y: Scanning laser Doppler flowmeter study of retinal blood flow in macular area of healthy volunteers. Br J Ophthalmol 2003;87:1469-1473.

-61 Dorner GT, Garhoefer G, Zawinka C, Kiss B, Schmetterer L: Response of retinal blood flow to CO2-breathing in humans. Eur J Ophthalmol 2002;12:459-466.

62 Wang Y, Bower BA, Izatt JA, Tan O, Huang D: Retinal blood flow measurement by circumpapillary Fourier domain Doppler optical coherence tomography. J Biomed Opt 2008; 13:064003.

-63 Yoshida A, Feke GT, Ogasawara H, Goger DG, McMeel JW: Retinal hemodynamics in middle-aged normal subjects. Ophthalmic Res 1996;28:343-350.

64 O’Day DM, Fish MB, Aronson SB, Pollycove $\mathrm{M}$, Coon A: Ocular blood flow measurement by nuclide labeled microspheres. Arch Ophthalmol 1971;86:205-209.

-65 Alm A, Bill A: Ocular and optic nerve blood flow at normal and increased intraocular pressures in monkeys (Macaca irus): a study with radioactively labelled microspheres including flow determinations in brain and some other tissues. Exp Eye Res 1973;15:1529.

66 Yoshida A, Feke GT, Mori F, Nagaoka T, Fujio N, Ogasawara H, Konno S, McMell JW: Reproducibility and clinical application of a newly developed stabilized retinal laser Doppler instrument. Am J Ophthalmol 2003;135:356-361.

67 Deng Y, Wang M, Duan J: The modality of huoxue-huayu in treatment of retinal vein occlusion. Yen Ko Hsueh Pao 1995;11:57-60.

-68 Izatt JA, Kulkarni MD, Yazdanfar S, Barton $\mathrm{JK}$, Welch AJ: In vivo bidirectional color Doppler flow imaging of picoliter blood volumes using optical coherence tomography. Opt Lett 1997;22:1439-1441.

69 White B, Pierce M, Nassif N, Cense B, Park B, Tearney G, Bouma B, Chen T, de Boer J: In vivo dynamic human retinal blood flow imaging using ultra-high-speed spectral domain optical coherence tomography. Opt Express 2003;11:3490-3497.

-70 Leitgeb RA, Schmetterer L, Hitzenberger CK, Fercher AF: Real-time measurement of in vitro flow by Fourier-domain color Doppler optical coherence tomography. Opt Lett 2004;2:171-173.
Wang Y, Bower BA, Izatt JA, Tan O, Huang D: In vivo total retinal blood flow measurement by Fourier domain Doppler optical coherence tomography. J Biomed Opt 2007;12: 041215.

72 Makita S, Fabritius T, Yasuno Y: Quantitative retinal-blood flow measurement with three-dimensional vessel geometry determination using ultrahigh-resolution Doppler optical coherence angiography. Opt Lett 2008;33:836-838.

73 Riva CE, Harino S, Petrig BL, Shonat RD: Laser Doppler flowmetry in the optic nerve. Exp Eye Res 1992;55:499-506.

74 Bonner R, Nossal R: Model for laser Doppler measurements of blood flow in tissue. Appl Opt 1981;20:2097-2107.

75 Michelson G, Schmauss B, Langhans MJ, Harazny J, Groh MJM: Principle, validity, and reliability of scanning laser Doppler flowmetry. J Glaucoma 1996;5:99-105.

76 Fercher AF, Briers JD: Flow visualization by means of single-exposure speckle photography. Opt Commun 1981;37:326-330.

77 Briers JD, Fercher AF: Retinal blood-flow visualization by means of laser speckle photography. Invest Ophthalmol Vis Sci 1982;22: 255-259.

78 Tamaki Y, Araie M, Kawamoto E, Eguchi S, Fujii H: Non-contact, two-dimensional measurement of microcirculation in choroid and optic nerve using laser speckle phenomenon. Exp Eye Res 1995;60:373-384.

79 Zinser G: Scanning laser Doppler flowmetry; in Pillunat LEH, Anderson A, Greve DR (eds): Current Concepts on Ocular Blood Flow in Glaucoma. The Hague, Kugler, 1999, pp 197-204.

80 Petrig BL, Riva CE, Hayreh SS: Laser Doppler flowmetry and optic nerve head blood flow. Am J Ophthalmol 1999;127:413425.

81 Riva CE: Basic principles of laser Doppler flowmetry and application to the ocular circulation. Int Ophthalmol 2001;23:183189.

82 Harris A, Shoemaker JA, Cioffi GA: Assessment of human ocular hemodynamics. Surv Ophthalmol 1998;42:509-533.

83 Lieb WE, Cohen SM, Merton DA, Shields JA, Mitchell DG, Goldberg BB: Color Doppler imaging of the eye and orbit: technique and normal vascular anatomy. Arch Ophthalmol 1991;109:527-531.

84 Riva CE, Schmetterer L: Microcirculation of the ocular fundus; in Tuma RF, Duran WN, Ley K (eds): Handbook of Physiology: Microcirculation. Amsterdam, Academic Press, 2008, pp 735-765.

85 Frangieh GT, Green WR, Barraquer-Somers E, Finkelstein D: Histopathologic study of nine branch retinal vein occlusions. Arch Ophthalmol 1982;100:1132-1140.

86 Hayreh SS: Prevalent misconceptions about acute retinal vascular occlusive disorders. Prog Retin Eye Res 2005;24:493-519.
87 Vilser W, Deufrains A, Dietze U, Seewald D, Büchner D, Königsdörffer E, Jütte A: Clinical interpretation of retinal circulatory measurements. IV. Photocoagulation in diabetic retinopathy and venous occlusive diseases (in German). Ophthalmologica 1986;193: 108-125.

- 88 Vilser W, Graser T, Leisner H, Deufrains A, Königsdörffer E, Seewald D, Friedrich R, Jütte A: Clinical interpretation of retinal circulatory measurements. III. Blood flow velocity and vessel diameter in normal persons and in patients with venous occlusive diseases (in German). Ophthalmologica 1986;193:97107.

89 Vilser W, Jütte A, Seewald D, Dietze U, Friedrich R, Königsdörffer E, Büchner D: Measurements of retinal microcirculation in retinal vessel occlusion before and after treatment. Graefes Arch Clin Exp Ophthalmol 1986;224:179-183.

90 Rosen DA, Marshall J, Kohner EM, Hamilton AM, Dollery CT: Experimental retinal branch vein occlusion in rhesus monkeys. II. Retinal blood flow studies. Br J Ophthalmol 1979;63:388-392.

-91 Peyman GA, Khoobehi B, Moshfeghi A, Moshfeghi D: Reversal of blood flow in experimental branch retinal vein occlusion. Ophthalmic Surg Lasers 1998;29:595-597.

92 Ben-nun J: Capillary blood flow in acute branch retinal vein occlusion. Retina 2001; 21:509-512.

93 Paques M, Naoun K, Garmyn V, Laurent P, Gaudric A: Circulatory consequences of retinal vein occlusions: advantages of dynamic angiography (in French). J Fr Ophtalmol 2002;25:898-902.

94 Avila CP Jr, Bartsch DU, Bitner DG, Cheng L, Mueller AJ, Karavellas MP, Freeman WR: Retinal blood flow measurements in branch retinal vein occlusion using scanning laser Doppler flowmetry. Am J Ophthalmol 1998; 126:683-690.

95 Donati G, Pournaras CJ, Pizzolato GP, Tsacopoulos M: Decreased nitric oxide production accounts for secondary arteriolar constriction after retinal branch vein occlusion. Invest Ophthalmol Vis Sci 1997;38: 1450-1457.

96 Donati G, Pournaras CJ, Tsacopoulos M: Effect of nitroprusside on arteriolar constriction after retinal branch vein occlusion. Invest Ophthalmol Vis Sci 1998;39:1910-1917.

97 Donati G, Pournaras CJ, Munoz JL, Poitry S Poitry-Yamate CL, Tsacopoulos M: Nitric oxide controls arteriolar tone in the retina of the miniature pig. Invest Ophthalmol Vis Sci 1995;36:2228-2237.

98 Attariwala R, Jensen PS, Glucksberg MR: The effect of acute experimental retinal vein occlusion on cat retinal vein pressures. Invest Ophthalmol Vis Sci 1997;38:2742-2749. 
-99 Iannaccone A, Letizia C, Pazzaglia S, Vin- 112 Grunwald JE, Riva CE, Brucker AJ, Sinclair golo EM, Clemente G, Pannarale MR: Plasma endothelin-1 concentrations in patients with retinal vein occlusions. Br J Ophthalmol 1998;82:498-503.

100 Haufschild T, Prunte C, Messerli J, Flammer J: Increased endothelin-1 plasma level in young adults with retinal vascular occlusive diseases. Klin Monatsbl Augenheilkd 2004;221:357-359.

-101 Stangos AN, Petropoulos IK, Pournaras JA, Mendrinos E, Pournaras CJ: The vasodilatory effect of juxta-arteriolar microinjection of endothelin A receptor inhibitor in healthy and acute branch retinal vein occlusion minipig retinas. Invest Ophthalmol Vis Sci 2010;51:2185-2190.

102 Kohner EM: Dynamic changes in the microcirculation of diabetics as related to diabetic microangiopathy. Acta Med Scand Suppl 1975;578:41-47.

$\checkmark 103$ Pournaras CJ, Rungger-Brandle E, Riva $\mathrm{CE}$, Hardarson SH, Stefansson E: Regulation of retinal blood flow in health and disease. Prog Retin Eye Res 2008;27:284-330.

104 Schmetterer L, Wolzt M: Ocular blood flow and associated functional deviations in diabetic retinopathy. Diabetologia 1999;42: 387-405.

105 Grunwald JE, DuPont J, Riva CE: Retinal haemodynamics in patients with early diabetes mellitus. Br J Ophthalmol 1996;80: 327-331.

-106 Feke GT, Buzney SM, Ogasawara H, Fujio N, Goger DG, Spack NP, Gabbay KH: Retinal circulatory abnormalities in type 1 diabetes. Invest Ophthalmol Vis Sci 1994;35: 2968-2975.

$>107$ Gilmore ED, Hudson C, Nrusimhadevara RK, Harvey PT, Mandelcorn M, Lam WC, Devenyi RG: Retinal arteriolar diameter, blood velocity, and blood flow response to an isocapnic hyperoxic provocation in early sight-threatening diabetic retinopathy. Invest Ophthalmol Vis Sci 2007;48:17441750.

- 108 Gilmore ED, Hudson C, Nrusimhadevara RK, Ridout R, Harvey PT, Mandelcorn M, Lam WC, Devenyi RG: Retinal arteriolar hemodynamic response to an acute hyperglycemic provocation in early and sightthreatening diabetic retinopathy. Microvasc Res 2007;73:191-197.

109 Grunwald JE, Brucker AJ, Grunwald SE, Riva CE: Retinal hemodynamics in proliferative diabetic retinopathy. A laser Doppler velocimetry study. Invest Ophthalmol Vis Sci 1993;34:66-71.

- 110 Fallon TJ, Maxwell DL, Kohner EM: Autoregulation of retinal blood flow in diabetic retinopathy measured by the blue-light entoptic technique. Ophthalmology 1987;94: 1410-1415.

$>111$ Sieker HO, Hickam JB: Normal and impaired retinal vascular reactivity. Circulation 1953;7:79-83.
$\mathrm{SH}$, Petrig BL: Altered retinal vascular response to $100 \%$ oxygen breathing in diabetes mellitus. Ophthalmology 1984;91:14471452 .

113 Takagi C, Bursell SE, Lin YW, Takagi H, Duh E, Jiang Z, Clermont AC, King GL: Regulation of retinal hemodynamics in diabetic rats by increased expression and action of endothelin-1. Invest Ophthalmol Vis Sci 1996;37:2504-2518.

114 Blum M, Vollrath D, Bartke T, Bachmann K, Strobel J: Vasoconstriction of retinal arterioles with oxygen breathing in diabetic retinopathy (in German). Ophthalmologe 2003;100:306-309.

115 Grunwald JE, Brucker AJ, Petrig BL, Riva CE: Retinal blood flow regulation and the clinical response to panretinal photocoagulation in proliferative diabetic retinopathy. Ophthalmology 1989;96:1518-1522.

116 Morgado PB, Chen HC, Patel V, Herbert L, Kohner EM: The acute effect of smoking on retinal blood flow in subjects with and without diabetes. Ophthalmology 1994; 101:1220-1226.

117 Bertram B, Wolf S, Arend O, Schulte K, Reim M: Retinal circulation and current blood glucose value in diabetic retinopathy (in German). Klin Monatsbl Augenheilkd 1992;200:654-657.

118 Bertram B, Wolf S, Fiehofer S, Schulte K, Arend O, Reim M: Retinal circulation times in diabetes mellitus type 1. Br J Ophthalmol 1991;75:462-465.

119 Atherton A, Hill DW, Young S, Edwards EJ: The effect of acute hyperglycaemia on the retinal circulation of the normal cat. Diabetologia 1980;18:233-237.

120 Ernest JT, Goldstick TK, Engerman RL: Hyperglycemia impairs retinal oxygen autoregulation in normal and diabetic dogs. Invest Ophthalmol Vis Sci 1983;24:985989.

121 Sullivan PM, Davies GE, Caldwell G, Morris AC, Kohner EM: Retinal blood flow during hyperglycemia. A laser Doppler velocimetry study. Invest Ophthalmol Vis Sci 1990;31:2041-2045.

122 Williamson JR, Chang K, Frangos M, Hasan KS, Ido Y, Kawamura T, Nyengaard JR, Van den Enden M, Kilo C, Tilton RG: Perspectives in diabetes. Hyperglycemic pseudohypoxia and diabetic complications. Diabetes 1993;42:801-813.

123 Tiedeman JS, Kirk SE, Srinivas S, Beach JM: Retinal oxygen consumption during hyperglycemia in patients with diabetes without retinopathy. Ophthalmology 1998;105:3136.

124 Fallon TJ, Sleightholm MA, Merrick C, Chahal P, Kohner EM: The effect of acute hyperglycemia on flow velocity in the macular capillaries. Invest Ophthalmol Vis Sci 1987;28:1027-1030.
125 Sullivan PM, Parfitt VJ, Jagoe R, Newsom $\mathrm{R}$, Kohner EM: Effect of meal on retinal blood flow in IDDM patients. Diabetes Care 1991; 14:756-758.

126 Waldhausl W, Freyler H, Bratusch-Marrain $\mathrm{P}$, Vierhapper $\mathrm{H}$, Bruneder $\mathrm{H}$ : Continuous subcutaneous insulin infusion: long-term treatment in an unselected group of insulin-dependent diabetics. Dtsch Med Wochenschr 1983;108:570-577.

127 Diabetes Control and Complications Trial Research Group: The effect of intensive treatment of diabetes on the development and progression of long-term complications in insulin-dependent diabetes mellitus. N Engl J Med 1993;329:977.

128 Frank RN: Diabetic retinopathy. Prog Retin Eye Res 1995;14:361-392.

129 Grunwald JE, Riva CE, Petrig BL, Brucker AJ, Schwartz SS, Braunstein SN, DuPont J, Grunwald S: Strict control of glycaemia: effects on blood flow in the large retinal vessels and in the macular microcirculation. Br J Ophthalmol 1995;79:735-741.

130 Grunwald JE, Brucker AJ, Schwartz SS, Braunstein SN, Baker L, Petrig BL, Riva CE: Diabetic glycemic control and retinal blood flow. Diabetes 1990;39:602-607.

131 Grunwald JE, Brucker AJ, Braunstein SN, Schwartz SS, Baker L, Petrig BL, Riva CE Strict metabolic control and retinal blood flow in diabetes mellitus. Br J Ophthalmol 1994;78:598-604.

132 Fuchsjager-Mayrl G, Kautzky-Willer A, Kiss B, Roden M, Wagner O, Pleiner J, Wolzt M, Schmetterer L: Ocular hyperperfusion following onset of intensified insulin therapy is inversely correlated with plasma endothelin-1 in type I diabetes. Diabetologia 2002;45:883-889.

133 Sinclair SH, Grunwald JE, Riva CE, Braunstein SN, Nichols CW, Schwartz SS: Retinal vascular autoregulation in diabetes mellitus. Ophthalmology 1982;89:748-750.

134 Rassam SM, Patel V, Kohner EM: The effect of experimental hypertension on retinal vascular autoregulation in humans: a mechanism for the progression of diabetic retinopathy. Exp Physiol 1995;80:53-68.

135 Dumskyj MJ, Eriksen JE, Dore CJ, Kohner EM: Autoregulation in the human retinal circulation: assessment using isometric exercise, laser Doppler velocimetry, and computer-assisted image analysis. Microvasc Res 1996;51:378-392.

136 Dumskyj MJ, Kohner EM: Retinal blood flow regulation in diabetes mellitus: impaired autoregulation and no detectable effect of autonomic neuropathy using laser Doppler velocimetry, computer assisted image analysis, and isometric exercise. $\mathrm{Mi}$ crovasc Res 1999;57:353-356.

137 Blum M, Pils C, Müller UA, Strobel J: The myogenic response of retinal arterioles in diabetic retinopathy (in German). Ophthalmologe 2006;103:209-213. 
138 Lanigan LP, Clark CV, Allawi J, Hill DW, Keen H: Responses of the retinal circulation to systemic autonomic stimulation in diabetes mellitus. Eye 1989;3:39-47.

139 Garhofer G, Zawinka C, Resch H, Kothy P, Schmetterer L, Dorner GT: Reduced response of retinal vessel diameters to flicker stimulation in patients with diabetes. $\mathrm{Br} \mathrm{J}$ Ophthalmol 2004;88:887-891.

140 Pemp B, Garhofer G, Weigert G, Karl K, Resch H, Wolzt M, Schmetterer L: Reduced retinal vessel response to flicker stimulation but not to exogenous nitric oxide in type 1 diabetes. Invest Ophthalmol Vis Sci 2009;50:4029-4032.

141 Mizutani M, Gerhardinger C, Lorenzi M: Muller cell changes in human diabetic retinopathy. Diabetes 1998;47:445-449.
42 Dawczynski J, Mandecka A, Blum M, Muller UA, Ach T, Strobel J: Endothelial dysfunction of central retinal vessels: a prognostic parameter for diabetic retinopathy? (in German). Klin Monatsbl Augenheilkd 2007;224:827-831.

143 Gordon MO, Beiser JA, Brandt JD, Heuer DK, Higginbotham EJ, Johnson CA, Keltner JL, Miller JP, Parrish RK 2nd, Wilson MR, Kass MA: The Ocular Hypertension Treatment Study: baseline factors that predict the onset of primary open-angle glaucoma. Arch Ophthalmol 2002;120:714720; discussion 829-830.

144 Leske MC, Wu SY, Hennis A, Honkanen R, Nemesure B: Risk factors for incident openangle glaucoma: the Barbados Eye Studies. Ophthalmology 2008;115:85-93.

145 Grunwald JE, Riva CE, Stone RA, Keates EU, Petrig BL: Retinal autoregulation in open-angle glaucoma. Ophthalmology 1984;91:1690-1694.
46 Hafez AS, Bizzarro RL, Rivard M, Lesk MR Changes in optic nerve head blood flow after therapeutic intraocular pressure reduction in glaucoma patients and ocular hypertensives. Ophthalmology 2003;110:201210.

147 Riva CE, Salgarello T, Logean E, Colotto A, Galan EM, Falsini B: Flicker-evoked response measured at the optic disc rim is reduced in ocular hypertension and early glaucoma. Invest Ophthalmol Vis Sci 2004; 45:3662-3668.

148 Garhofer G, Zawinka C, Resch H, Huemer $\mathrm{KH}$, Schmetterer L, Dorner GT: Response of retinal vessel diameters to flicker stimulation in patients with early open angle glaucoma. J Glaucoma 2004;13:340-344. 